DOI: $\square$ https://doi.org/10.15407/techned2020.04.025

\title{
ACTIVE SHIELDING OF MAGNETIC FIELD Of OVERHEAD POWER LINE WITH PHASE CONDUCTORS OF TRIANGLE ARRANGEMENT
}

Journal

Publisher

ISSN

Issue

Pages
Tekhnichna elektrodynamika

Institute of Electrodynamics National Academy of Science of Ukraine 1607-7970 (print), 2218-1903 (online)

No 4, 2020 (July/August)

$25-28$

\section{Authors}

\section{B.I. Kuznetsov ${ }^{1 *}$, T.B. Nikitina ${ }^{2 * \star}$, I.V. Bovdui ${ }^{1 * \star *}$}

1- Institute of Technical Problems of Magnetism National Academy of Sciences of Ukraine, 19, Industrialna st., Kharkiv, 61106, Ukraine, e-mail: e-mail: kuznetsov.boris.@@gmail.com

2. Kharkov National Automobile and Highway University,

25, Yaroslava Mudroho st., Kharkiv, 61002, Ukraine.

* ORCID ID : https://orcid.org/0000-0002-1100-095X

** ORCID ID : https://orcid.org/0000-0002-9826-1123

*** ORCID ID : https://orcid.org/0000-0003-3508-9781

\section{Abstract}

For the first time in Ukraine the synthesis of two degree of freedom robust two-circuit system of active shielding of magnetic field, generated by overhead power lines with triangle arrangements of phase conductors is realized to reduce the magnetic flux density down to the sanitary standards level and to reduce the sensitivity of the system to plant parameters uncertainty. The synthesis is based on the multi-criteria stochastic game solution, in which the payoff vector is calculated by the solutions of the Maxwell equations as a quasi-stationary approximation. The game solution is based on the stochastic multi-swarm particle optimization algorithms. The computer simulation and field experimental results of two degree of freedom robust two-circuit system of active shielding of magnetic field, generated by overhead power lines with triangle arrangement of phase conductors are presented. References 6 , figures 3. 
Key words: overhead power lines, triangle arrangement of phase conductors, magnetic field, system of active shielding, computer simulation, field experimental study.

Received: 28.02.2020

Accepted: 26.03.2020

Published: 26.06.2020

\section{References}

1. Rozov V., Grinchenko V. Simulation and analysis of power frequency electromagnetic field in buildings closed to overhead lines. IEEE First Ukraine Conference on Electrical and Computer Engineering 2017. Pp. 500-503. (UKRCON). Kyiv, Ukraine, May 29-June 2, DOI: https://doi.org/10.110 9/UKRCON.2017.8100538

2. Active Magnetic Shielding (Field Cancellation). URL: http://emfservices.com/afcs.htm (Accessed date: 05.11.2019).

3. Celozzi S., Garzia F. Active shielding for power-frequency magnetic field reduction using genetic algorithms optimization. IEE Proceedings - Science, Measurement and Technology. 2004. Vol. 151. No. 1. Pp. 2-7. DOI:

https://doi.org/10.1049/ip-smt:20040002

4. Araki M., Taguchi H. Two-degree-of-freedom PID controllers. International Journal of Control, Automation, and Systems 2003. Vol. 1, No. 4. Pp. 401-411.

5. Ummels M. Stochastic Multiplayer Games Theory and Algorithms. Amsterdam: Amsterdam University Press, 2010. DOI: https://doi.org/10.5117/9789085550402

6. Kuznetsov B.I., Nikitina T.B., Kolomiets V.V., Bovdui I.V., Voloshko A.V., Vinichenko E.V. Synthes of robust active shielding systems of magnetic field generated by group of high-voltage power lines. Electrical Engineering \& Electromechanics. 2018. No 5. Pp. 34-38. DOI: https://do i.org/10.20998/2074-272X/2018.5.06 


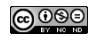

This work is licensed under a Creative Commons Attribution-NonCommercial-NoDerivatives $\underline{4.0 \text { International License }}$ 